\title{
The developmental transcriptome of Drosophila melanogaster
}

Brenton Graveley

From Beyond the Genome: The true gene count, human evolution and disease genomics

Boston, MA, USA. 11-13 October 2010

Drosophila melanogaster is one of the well-studied metazoan organisms; nonetheless its genome still contains unannotated genes, exons and RNA editing sites. Furthermore, our understanding of how the regulation of transcription, splicing and RNA editing directs development of this complex organism remains limited. We have used RNA-seq, tiling microarrays and cDNA sequencing to explore the transcriptome in 30 distinct stages throughout development. We have identified 87,352 new features, including thousands of genes, coding and non-coding transcripts, exons, splicing and editing events. We have inferred protein isoforms that previously eluded discovery with established experimental, prediction and conservation-based approaches. Together, these data substantially expand the number of known transcribed elements in the Drosophila genome and provide a high-resolution view of transcriptome dynamics throughout the development of a metazoan.

Published: 11 October 2010

Submit your next manuscript to BioMed Central and take full advantage of:

- Convenient online submission

- Thorough peer review

- No space constraints or color figure charges

- Immediate publication on acceptance

- Inclusion in PubMed, CAS, Scopus and Google Scholar

- Research which is freely available for redistribution

Submit your manuscript at www.biomedcentral.com/submit
C Biomed Central 